\title{
Stress and Students Mindset
}

\author{
Jerald C. Moneva \\ Department of Education-Mandaue City Division \\ Mandaue City, Cebu, Philippines \\ Tel: +63908-927-3038Ｅ-mail: Freezingfire1979@gmail.com
}

\author{
Ana Marie Inting \\ Jagobiao National High School \\ Jagobiao, Mandaue City, Cebu, Philippines \\ Tel: +63966-357-2094Ｅ-mail: anamarieinting@gmail.com
}

\author{
Eugenia M. Solon \\ Department of Education-Division of Cebu Province \\ Cang- Oyao Bitoon, Daanbantayan, Cebu, Philippines
}

Tel:+63917-100-7411Ｅ-mail: eugeniasolon5@gmail.com

Received: Jan. 9, 2020 Accepted: Jan. 31, 2020 Published: Feb. 27, 2020

doi:10.5296/ijssr.v8i1.16565 URL: http://dx.doi.org/10.5296/ijssr.v8i1.16565

\begin{abstract}
The purposes of the study were to investigate; firstly, the type of mindset did the students have either fixed or growth mindset; secondly, to examine the level of stress in relation to their academics; and thirdly, to know the relationship of mindset and students stress level. The data collected for this study has been gathered from all Senior High School students with a sample $(\mathrm{n}=245)$. The study used checklist-questionnaire composed of thirty five questions in examining students' mindset, level of stress and its relationship. Results indicates that mindset of students doesn't have any relation to stress. Moreover, it has been found that most of the Senior High School students have growth mindset but neither of the two mindsets has to do with stress.
\end{abstract}

Keywords: Beliefs, Fixed mindset, Growth mindset, Stress level 


\section{$\Lambda$ Macrothink}

\section{Introduction}

\subsection{Rationale}

Stress is a state of mental tension and worry caused by problems in your life, work, etc. Mindset is a particular way of thinking; a person's attitude or set of opinions about something (Merriam Webster). But improving one's response to stress may be a matter of shifting one's mindset. There are two types of mindset, fixed mindset in which people believe their qualities are fixed traits and growth mindset in which people have an underlying belief that their learning and intelligence can grow with time and experience (Dweck, 2006).

The researcher believes that studying the mindset; develop a mindset that has a direct sequel on the student's motivation to avoid stress. Increasing students' motivation to study, learn and build academic skills, they are better prepared to learn, perform in the future, and so avoids stress. When the students know their innate mindset and know how to use or change it for the better, the students won't worry too much about problems that include school related problems.

Students mindset brings achievement in studies (Mangels, Butterfield, Good, Lamb, \& Dweck, 2006). However, in a world of fixed mindset, the substandard is effort. It means that a person is not splendid at all. In the realm of growth mindset, effort is what make superior in everything and growth mindset is not just about effort but also finding strategies to improve people's actual self (Dweck, Walton, \& Cohen, 2006).

In this study, the researcher will know the relationship of mindset and stress level of students.

\subsection{Theoretical Background}

Carol S. Dweck proposed a theory in 2006 to be a way to understand the sequel of beliefs in intelligence and everyday doings Dweck wanted to figure the belief that ability can improve through embracing and facing challenges. The ability of mindset in developing a person's ability, intelligence, attitude, personality, and behavior. Out why some people achieve their implicit potential but equally talented person don't. Dweck come up with the thought that it is not about the ability that something that can be develop or improve, that is the reason why Dweck study the mindset (Dweck, 2006).

The Growth and Fixed mindset, growth mindset is the people beliefs that their learning and intelligence can grow with time and experience. The beliefs of a person that everything can be develop or improve by effort.

Fixed mindset is the people belief that their qualities are fixed traits. The belief of a person that their ability, intelligence, attitude, personality, and behavior are fixed or naturally occurred from the day they are born and can never be change.

Studying the mindset, the fixed and growth mindset may be an indication on how student cope up when facing stress or an indication that who most likely to get stress, the students who have a fixed or a growth mindset. 


\subsection{Statement of Purpose}

The study intends to know the level of the mindset in terms of growth and fixed, then stress level of students, assess there is a relationship between mindset and stress level of students.

\subsection{Review of Related Literature}

Mindset has a very important role in adolescent special education students for it has an effect on students' self-efficacy and motivation (Rhew, Piro, Goolkasian, \& Consentino, 2018). Building up beliefs is a way or the key to success (Gbollie \& Keamu, 2017). If we consider the influence of mindset, it is possible to create a brighter future (Buchanan \& Kern, 2018); affects academic achievement (Zhang, Kuusisto, \& Tirri, 2017). But other study shows that mindset does not have an impact on students' academic achievement (Bazelais, Lemay, Doleck, Hu, Vu, \& Yao, 2018). However, it has an impact on decision making but differs on individual differences (Barry \& Halfman, 2016); important in developing people's ability and intelligence with effort and practice (Boaler, 2013).

By improving students'resiliency, mindset can predict students' psychological well-being and school engagement (Zheng, Hou, \& Peng, 2016). Yet, the mindset of students can change with personality intervention (Schroder, Yalch, Dawood, Callahan, Donnellan, \& Moser, 2017). Mindset considered as a belief of people and it has a direct impact to the students' self-efficacy and conceptions of learning (Sali \& Dagyar, 2015). Self-efficacy is also a leading factor and influence students learning (Adams, Finkelstein, Pollock, \& Wieman, 2005; Valentine, Dubois, \& Cooper, 2004). And has an impact on students' behavior with mindset intervention (Orawiwathakul \& Wichadee, 2017). It also affects students' success, those students with high efficacy have the possibility to improve and succeed than those students who have low-efficacy (Ahmad \& Safaria, 2013). Students' beliefs have an impact on students' success by the power of demand characteristics and mindset intervention (Burgoyne, Moser, Hambrick, \& Burt, 2018).

Just like mindset, stress can also affects the students, academic performance and learning (Halder, 2018; Saqib \& Rehman, 2018; Shahzad, Rehman, \& Saqib, 2018). But with age intervention; older students can deal with their problems that can lessen the effects of stress (Oboth \& Odiemo, 2018; Khan, 2018). But other study shows that stress doesn't have any impact on academic performance and achievement (Elias, Ping, \& Abdullah, 2011). Stress doesn't only affect students' academic performance but also students' heath (Shaikh, Khan, Khalid, \& Khan, 2004; Shahsavavani, Abadi, \& Kalkhoran, 2015). Stress has many harmful effects on people's health but it varies on people's response to stress (Yaribeygi, Panahi, Sahraci, Johnston, \& Sahebkar, 2017). It also effects on mental health but differs on people's self-efficacy (Schonfeld, Brailovskaia, Bieda, Zhang, \& Margraf, 2015). Stress also affects relationship behavior (Lewandowski \& Mattingly, 2014); can lead to loneliness, nervousness, sleeplessness, and worrying (N \& Shastri, 2016). Stress can decreased students motivation that can also leads to absenteeism and incompletion of school works (Sasikala, Hemamalini, \& Ashok, 2018). Study shows that females experience stress more than males (Bamuhair, Farhan, Althubaiti, Agha, Rahman, \& Ibrahim, 2015). Stress can also reduce or lessen students enjoyment, achievement, and has an impact on relationship (Mazumdar, Gogo, 


\section{Mll Macrothink}

Buragohan, \& Haloi, 2012).

\section{Research Method}

\subsection{Design}

This study used descriptive correlational as a design. The design described the correlation of mindset and the stress levels of students. The researcher used this design due to its suitability of the study.

\subsection{Environment}

The study was conducted at Senior High School building of Jagobiao National High School which located at Jagobiao, Mandaue City. This school offers K to 12 program (SHS), the Humanities and Social Sciences (HUMSS), Science, Technology, Engineering and Mathematics (STEM), General Academic Track (GAS), and Technical Vocational and Livelihood (TVL).

\subsection{Respondents}

The respondents of the study were the Senior High School students of Jagobiao National High School that composed of 245 students in which 148 are the grade 11 students and 97 are the grade 12 students. The respondents were chosen to answer the research purposes.

\subsection{Data Gathering Procedure}

The researcher asked permission from the school principal, Senior High School teachers and students particularly with Grade 12 and to 11 students to conduct the study.

The researcher used a checklist - questionnaire as a tool of this study. The respondents were given 10 minutes to answer the checklist - questionnaire that composed of 35 questions and after gathering the data, the researcher tabulated, analyzed and interpreted the results to achieve the goal of the study.

\subsection{Instrument}

The researcher used a checklist - questionnaire as a tool of this study. The tool composed of 35 questions in which 10 questions for fixed mindset, another 10 questions for growth mindset, and 15 questions for stress.

The respondents rate each indicator as 1-3 in which 1 for never, 2 for sometimes and 3 for always. 


\section{Macrothink

\section{Data Analysis and Discussion}

Table 1. Fixed mindset

\begin{tabular}{llc}
\hline INDICATORS (FIXED MINDSET) & WM & Interpretation \\
\hline 1. I see workloads as a burden & 2.01 & Sometimes \\
2. I see effort is pointless & 1.92 & Sometimes \\
3. Easily quit or give up & 1.80 & Sometimes \\
4. I avoid taking up challenges & 1.84 & Sometimes \\
5. I criticize and judge others & 1.77 & Sometimes \\
6. I believe that my intelligence are inborn & 1.86 & Sometimes \\
7. I believe that my talent is fixed & 1.92 & Sometimes \\
8. I believe that, if I am not good in a particular subject then I forever am & 1.78 & Sometimes \\
9. I easily think that I can't do it & 2.05 & Sometimes \\
10. I get easily tired when making outputs & 2.05 & Sometimes \\
OVERALL WEIGHTED MEAN & $\mathbf{1 . 9 0}$ & Sometimes \\
\hline
\end{tabular}

SCALE: 1- 1.67- (Never) 1.68- 2.34- (Sometimes) 2.35-3- (Always)

The table above shows the weighted mean of the level of students who have fixed mindset in Grade 11 and 12. The overall weighted mean is 1.90 which is interpreted as Sometimes. The three highest weighted mean are indicator no.9 "I easily think that I can't do it" which is 2.05 , indicator no.10 "I get easily get tired when making outputs" which is 2.05 and indicator no. 1 "I see workloads as a burden" which is 2.01 , and the three highest indicators interpreted as "sometimes". While the three lowest of weighted means are indicator no. 5 "I criticize and judge others" which is 1.77 , indicator no.8 "I believe that, if I am not good in a particular subject then I forever am" which is 1.78 and indicator no.3 "Easily quit or give up" which is 1.80 and these three lowest weighted mean interpreted as Sometimes. A person who have a fixed mindset can easily judge and under-estimate other people (Murphy \& Thomas, 2008). And believe that their abilities are limited (Dweck, Walton, \& Cohen, 2014). 
Table 2. Growth mindset

\begin{tabular}{lll}
\hline INDICATORS (GROWTH MINDSET) & WM & Interpretation \\
\hline 1. I believe that abilities can be develop & 2.67 & Always \\
2. I accept and embrace challenges & 2.45 & Always \\
3. I see mistakes as a learning opportunities & 2.61 & Always \\
4. I take risks & 2.39 & Always \\
5. I try new things & 2.48 & Always \\
6. I believe that effort and challenges can make me develop & 2.69 & Always \\
7. I believe that I can do everything through effort & 2.62 & Always \\
8. I believe that I can do well in class even if there are problems & 2.34 & Sometimes \\
9. I believe that my talent can be improved & 2.57 & Always \\
10. I believe that improvement corresponds effort & 2.59 & Always \\
OVERALL WEIGHTED MEAN & $\mathbf{2 . 5 4}$ & Always \\
\hline
\end{tabular}

SCALE: 1- 1.67-(Never) 1.68- 2.34- (Sometimes) 2.35-3-(Always)

The table above shows the weighted mean of the level of students who have a growth mindset in Grade 11 and 12. The overall weighted mean is 2.54 which is interpreted as Always. The three highest weighted mean are indicator no.6 "I believe that effort and challenges can make me develop" which is 2.69 , indicator no.1 "I believe that abilities can be develop" which is 2.67 and indicator no.7 "I believe that I can do everything through effort" which is 2.62, and the three highest indicators interpreted as "Always". While the three lowest of weighted means are indicator no. "I believe that I can do well in class even if there are problems" which is 2.34 interpreted as "Sometimes" indicator no.4 "I take risks" which is 2.39 and indicator no.2 "I accept and embrace challenges" which is 2.45 and the other two that had lowest weighted mean interpreted as "Always". In contrast, if a person has a growth mindset, students can easily understand the lessons (Dweck, Walton, \& Cohen, 2014). And can easily cope in any challenges (Murphy \& Thomas, 2008).

Table 3. Stress physical indicators

\begin{tabular}{lll}
\hline STRESS (PHYSICAL INDICATORS) & WM & Interpretation \\
\hline 1. My body feels tense all over & 2.05 & Sometimes \\
2. I have a nervous sweat or sweaty palms & 2.06 & Sometimes \\
3. I have a hard time feeling really relaxed & 2.07 & Sometimes \\
4. I get severe or chronic headaches & 1.97 & Sometimes \\
5. I get tension or muscle spasm in my face, jaw, neck, or shoulders & 1.89 & Sometimes \\
OVERALL WEIGHTED MEAN & $\mathbf{2 . 0 1}$ & Sometimes \\
\hline
\end{tabular}

SCALE: 1- 1.67- (Never) 1.68- 2.34- (Sometimes) 2.35- 3- (Always)

The table above shows the weighted mean of the level of stress of students in Physical aspects. The overall weighted mean is 2.01 interpreted as "Sometimes". The highest weighted 
mean is indicator no.2"I have a nervous sweat or sweaty palms" which is 2.06 interpreted as "Sometimes". The lowest weighted mean is indicator no.5 "I get tension or muscle spasm in my face, jaw, neck, or shoulders" which is, 1.89 interpreted as "Sometimes". In addition, stress can cause over eating, depression and headaches in students (Bhargava \& Trivedi, 2018). But stress can also be the reason for people survival by the involvement of preserving homeostasis of cells/species (Yaribeygi, Panahi, Sahraci, Johnston, \& Sahebkar, 2017).

Table 4. Stress sleep indicators

\begin{tabular}{lll}
\hline SLEEP INDICATORS & WM & Interpretation \\
\hline 1. I have trouble falling asleep & 1.94 & Sometimes \\
2. I take pills to go to sleep & 1.23 & Never \\
3. I have nightmares or repeated bad dreams & 1.87 & Sometimes \\
4. I wake up at least once in the middle of the night for no apparent reason & 2.11 & Sometimes \\
5. No matter how much sleep I get, I wake up feeling tired & 2.24 & Sometimes \\
OVERALL WEIGHTED MEAN & $\mathbf{1 . 8 8}$ & Sometimes \\
\hline
\end{tabular}

SCALE: 1- 1.67- (Never) 1.68-2.34- (Sometimes) 2.35-3- (Always)

The table above shows the weighted mean of the level of stress of students in Sleep aspects. The overall weighted mean is 1.88 which is interpreted as "Sometimes". The highest weighted mean is indicator no.5 "No matter how much sleep I get, I wake up feeling tired" which is 2.24 interpreted as "Sometimes". The lowest weighted mean is indicator no.2 "I take pills to go to sleep" which is 1.23 interpreted as "Never". Fatique can also be a result of stress (Kocalevent, Hinz, Brähler, \& Klapp, 2011). And insomia is also a result of stress (Han, Kim, \& Shim, 2012).

Table 5. Stress emotional indicators

\begin{tabular}{lll}
\hline EMOTIONAL INDICATORS & WM & Interpretation \\
\hline 1. I have trouble remembering things & 2.19 & Sometimes \\
2. I feel anxious or frightened about problems I can't really describe & 2.04 & Sometimes \\
3. I worry a lot & 2.16 & Sometimes \\
4. I have temper outburst I can't control & 2.04 & Sometimes \\
5. It is best if I don't even tell even my closest friend how I'm really feeling & 2.07 & Sometimes \\
OVERALL WEIGHTED MEAN & $\mathbf{2 . 1 0}$ & Sometimes \\
\hline
\end{tabular}

SCALE: 1- 1.67- (Never) 1.68-2.34- (Sometimes) 2.35-3- (Always)

The table above shows the stress level of students in emotional aspects. The overall weighted mean is 2.10 interpreted as "Sometimes". The highest weighted mean is indicator no.1 "I have trouble remembering things" which is 2.19 interpreted as "Sometimes". The lowest weighted mean are indicator no. 2 "I feel anxious or frightened about problems I can't really 
describe" and indicator no.4 "I have temper outburst I can't control" which have 2.04 weighted mean interpreted as "Sometimes". Stress affects people's memory (Vogel \& Schwabe, 2016). And can cause anxiety (Khan S. \& Khan R.A, 2017).

Table 6. Comparison of mindset and indicators of stress.

\begin{tabular}{lllllll}
\hline & & Sum of Squares & df & Mean Square & F & Sig. \\
\hline \multirow{4}{*}{ Physical } & Between Groups & 12.506 & 1 & 12.506 & 3.027 & .083 \\
& Within Groups & 950.145 & 230 & 4.131 & & \\
& Total & 962.651 & 231 & & & \\
\hline \multirow{4}{*}{ Sleep } & Between Groups & 8.521 & 1 & 8.521 & 3.099 & .080 \\
& Within Groups & 632.336 & 230 & 2.749 & & \\
& Total & 640.858 & 231 & & & \\
Emotional & Wetween Groups & .013 & 1 & .013 & .003 & .953 \\
& Within Groups & 887.918 & 230 & 3.861 & & \\
& Total & 887.931 & 231 & & & \\
\hline
\end{tabular}

The table above shows the value computed to test the significance and the association of mindset in stress specifically in physical, sleep, and emotional indicators of stress. The $\mathrm{P}$-value (0.83) of physical indicator of stress is greater than the level of significance, alpha $(0.05)$ which do not reject the null hypothesis $(0.083<0.05)$ and the relationship between the two variables are not significant. This implies that students' mindset doesn't have any relation to the stress levels of students in physical aspects. In contrast, stress can caused diseases (Schneiderman, Ironson, \& Siegel, 2005). And can cause disorders (Yarabeygi, Panahi, Sahraei, Johnston, \& Sahebkar, 2017).

The P-value (0.080) of sleep indicator of stress is greater than the level of significance, alpha $(0.05)$ which do not reject the null hypothesis $(0.080<0.05)$ and the relationship between the two variables are not significant. Consequently, stress has an effect in sleep (Becker, Jesus, Marguilho, Viseu, Del Rio, Gualberto, \& Casal, 2015). It can cause sleep disorder but can be avoided by managing everyday stress (Han, Kim, \& Shim, 2012).

This implies that students mindset doesn't have any relation to stress in sleep aspects and the P-value (0.953) of emotional indicator of stress is also greater than the significance level alpha (0.05) which is do not reject the null hypothesis $(0.953<0.05)$, the relationship between the two variables is also not significant. This implies that student's mindset doesn't have any relation to stress in emotional aspects. To sum up, mindset has nothing to do with stress. In addition, if a person is emotionally stressed, it can cause a severe effect in a person's health (Altaf, Noushad, Ahmed, Azher, \& Tahir, 2014). And if students are more emotionally stress than physically stress, there's a possibility that it will distract their concentration and can cause behavioral stress (Jayakumar \& Sulthan, 2013). 


\section{Findings}

The main objective of the study is to know if students' mindset has an association on stress on the students of Jagobiao National High School.

The table no. 1 shows the first variable mindset specifically on fixed mindset. It shows thatthe overall weighted mean is 1.90 which is interpreted as Sometimes. The table no. 2 shows also the first variable that focused on growth mindset. It shows that the overall weighted mean is 2.54 which is interpreted as Always. The table no.3 shows the second variable that focused on Stress in physical aspects as an indicator.The overall weighted mean is 2.01 interpreted as "Sometimes". The table no.4 shows also the second variable that focused on Stress in sleep aspects as an indicator. The overall weighted mean is 1.88 which is interpreted as "Sometimes". The table no. 5 focused on stress in emotional aspects as an indicator. The overall weighted mean is 2.10 interpreted as "Sometimes". The last table shows the association of mindset and stress with 3 indicators by the used of Anova. All 3 indicators of stress accepted the null hypothesis, not significant and don't have any relation to mindset.

\section{Conclusion}

Most of the students of senior high school hold a growth mindset. The belief in which, student believes that intelligence can improve by effort, dedication and hard work. It is the mindset that is capable in accepting failures and making it as a motivation to grow. Meanwhile, the students stress level interpreted as "sometimes" based on the overall weighted mean of the physical, sleep and emotional indicators of stress. When the students are stress, students mostly get nervous sweat or sweaty palms, waking up tired no matter how much sleep students get and have trouble remembering things. Stress can enhance mindset when the stress assessed as a challenge (Crum, Akinola, Martin, \& Fath, 2017). It is not the effect of stress; it is how the students deal with stress to maintain a quality relationships and life (Lewandowski, Mattingly, $\&$ Pedreiro, 2014). Thus, having a growth mindset can help the students to improve students' self-efficacy and motivation (Rhew, Piro, Goolkasian, \& Consentino, 2018).

\section{Recommendation}

The researcher recommends the students to have a growth mindset rather than fixed mindset for the students to have a good view of life that has an impact on their academic success, learnings and everyday lives. Research some strategies and techniques on how to cope up stress to avoid health (Physical, Emotional, Social, and Mental) and body issues.

\section{References}

Adams, W., Finkelstein, N., Pollock, S., \& Wieman, C. E. (2005). Correlating student beliefs with student learning attitudes about science survey. IOSR Journal of Humanities and Social Science. https://doi.org/10.1063/1.2084701

Ahmad, A., \& Safaria, T. (2013). Effects of self-efficacy on students' academic performance. Journal of Education, Health and Community Psychology, 2. Retrieved from https://www.researchgate.net/publication/263162945_Effects_on_Students'_Academic_Perfo rmance 
Altaf, N., Ahmed, A., \& Tahir. (2014). Emotional stress estimation in general population. International Journal of Endorsing Health Science Research. https://doi.org/10.29052/IJEHSR.v2.i1.2014.34-37

Bamuhair, S., Farhan, A., Althubaiti, A., Agha, S., Rahman, S., \& Ibrahim, N. (2015). Sources of stress and coping strategies among undergraduate medical students enrolled in a problem-based learning curriculum. Journal of Biomedical Education, 2015. https://doi.org/10.1155/2015/575139

Bazelais, P., Lemay, D. J., Doleck, T., Hu, X. S., Vu, A., \& Yao, J. (2018). Grit mindset and academic performance: A study of pre-university science students. EURASIA Journal of Mathemathics, Science and Technology Education, 14(12). https://doi.org/10.29333/ejmste/94570

Becker, J., Marguilho, V., Del Rio, G., \& Casal. (2015). Sleep quality and stress: a literature review. Advanced Research in Health, Education and Social Sciences (pp. 53-61). Retrieved from

https://www.researchgate.net/publication/301350658_Sleep_quality_and_stress_a_literature_ review

Bhargava \& Trivedi (2018). A study of causes of stress and stress management among youth. IRA-International Journal of Management \& Social Sciences, 11(3). https://doi.org/10.21013/jmss.v11.n3.p1

Boaler, J. (2013). Ability and mathematics: the mindset revolution that is reshaping education. Forum, 55. https://doi.org/10.2304/forum.2013.55.1.143

Buchanan, A., \& Kern, M. L. (2017). The benefit mindset: The psychology of contribution and everyday leadership. International Journal of Wellbeing, 7(1), 1-11. https://doi.org/10.5502/ijw.v7i1.538

Crum, A., Akinola, M., Martin, A., \& Fath, S. (2017). The role of stress mindset in shaping cognitive, emotional, and physiological responses to challenging and threatening stress. Journal of Personality and Social Psychology, 104(4), 716-733. https://doi.org/10.1037/a0031201

Dweck, C. S. (2006). Mindset: the new psychology of success. Retrieved from https://www.amazon.com/Mindset-Psychology-Carol-S-Dweck/dp/0345472322

Dweck, C. S., Walton, G. M., \& Cohen, G. L. (2014). Academic tenacity: mindsets and skills that promote long-term learning. Retrieved from https://ed.stanford.edu/sites/default/files/manual/dweck-walton-cohen-2014.pdf

Ellias, H., Ping, W. S., \& Abdullah, M. C. (2011). Stress and academic achievement among undergraduate students in university putra Malaysia. Procedia - Social and Behavioral Sciences, 646-655 https://doi.org/10.1016/j.sbspro.2011.11.288

Gbollie, C., \& Keamu, H. P. (2017). Student academic performance: The role of motivation, strategies, perceived factors hindering liberian junior and senior high school students learning. 
Educational Research International. https://doi.org/10.1155/2017/1789084

Halder, U. K. (2018). Academic stress and academic performance among higher secondary students: a gender analysis. International Journal of Creative Research Thoughts, 6 . Retrieved from

https://www.academia.edu/37299362/Academic_Stress_and_Academic_Performance_among Higher_Secondary_Students_A_Gender_Analysis

Halfman, K., \& Barry, C. (2016) The effect of mindset on decision making. The Journal of Integrated Social Sciences, 6(1), 49-74. Retrieved from http://www.jiss.org/documents/volume_6/JISS\%202016\%206(1)\%2049-74\%20Mindset\%20o $\mathrm{n} \%$ 20Decision.pdf

Han, K., Kim, L., \& Shim, I. (2012). Stress and Sleep Disorder. Experimental neurobiology. https://doi.org/10.5607/en.2012.21.4.141

Hermamalini, R., Ashok, V., \& Sasikala, V. (2018). A study on stress management and its impact among students. International Journal of Academic Research in Economics and Management Sciences, 7(3), 101-110.

Jayakumar, D. S., \& Sulthan, A. (2013). Stress symptoms: structural equation modelling. Journal of Indian Management, 13, 95-109. Retrieved from https://www.researchgate.net/publication/265421912_Stress_Symptoms_Structural_Equation Modelling

Khan, M. J., Altaf, S., \&Kausar, H. (2018). Effect of perceived academic stress on students' performance. FWU Journal of Social Sciences, 7(2), 146-151. Retrieved from https://www.researchgate.net/publication/327280770_Effect_of_Perceived_Academic_Stress on_Students'_Performance

Kocalevent, R. D., Hinz, A., Brähler, E., \& Klapp, B. F. (2011). Determinants of fatigue and stress. BMC Research Notes, 4, 238. https://doi.org/10.1186/1756-0500-4-238

Lewandowski, G., Mattingly, B., \& Pedreiro, A. (2014). Under pressure: The effects of stress on positive and negative relationship behaviors. The Journal of Social Psychology. https://doi.org/10.1080/00224545.2014.933162

Mangels, J. A., Butterfield, B., Lamb, J., Good, C., \& Dweck, C. S. (2006). Why do beliefs about intelligence influence learning success? A social cognitive neuroscience model. Social Cognitive and Affective Neuroscience. https://doi.org/10.1093/scan/ns1013

Mazumdar, H., Gogoi, D., Buragohain, L., \& Haloi, N. (2012). A comparative study on stress and its contributing factors among the graduate and post-graduate students. Advances in Applied Science Research, 3(1), 399-406. Retrieved from http://www.imedpub.com/articles/a-comparative-study-on-stress-and-its-contributing-factorsamong-thegraduate-and-postgraduate-students.pdf

Murphy, \&Thomas. (2008). Dangers of a fixed mindset: implications of self-theories research for computer science education abstract. Computer Science Education. 
https://doi.org/10.1145/1384271.1384344

N. V. \& Shailaja, S. (2016). The International Journal of Indian Psychology, 3. Retrieved from https://www.ijip.in

Oboth, J. W. B., \& Odiemo, L. (2018). The relationship between levels of stress and academic performance among university of nairobi students. International Journal of Learning and Development, 8(4). https://doi.org/10.5296/ijld.v8i4.13840

Pascoe, M. C., Hetrick, S. E., \& Parker, A. G. (2019). The impact of stress on students in secondary school and higher education. International Journal of Adolescence and Youth. https://doi.org/10.1080/02673843.2019.1596823

Rhew, E., Piro, J., Goolkasian, P., \& Consentino, P. (2018). The effects of a growth mindset on self-efficacy and motivation. Cogent Education. https://doi.org/10.1080/2331186X.2018.1492337

Sadi, O., \& Dagyar, M. (2015). High school students' epistemological beliefs, conceptions of learning, and self-efficacy for learning biology: A study of their structural models. Eurasia Journal of Mathematics, Science \& Technology Education, 11(5), 1061-1079. https://doi.org/10.12973/eurasia.2015.1375a

Sajib, M., \&Rehman, K. (2018). Impact of stress on students' academic performance at secondary school level at district Vehari. International Journal of Learning and Development, 8(1). https://doi.org/10.5296/ijld.v8i1.12063

Schneiderman, N., Ironson, G., \& Siegel, S. D. (2005). Stress and health: psychological, behavioral, and biological determinants. Annual Review of Clinical Psychology, 1, 607-628. https://doi.org/10.1146/annurev.clinpsy.1.102803.144141

Schonfeld, P., Brailovskaia, J., Bieda, A., Zhang, X. C., \& Margaf, J. (2015). International Journal of Clinical and Health Psychology, 16, 1-10. https://doi.org/10.1016/j.ijchp.2015.08.005

Shaikh, B.T., Khan, N., Khalid, H., \& Khan, S. (2004). Students, stress and coping strategies: a case of pakistani medical school. Education for Health. https://doi.org/10.1080/13576280400002585

Shahsavarani, A. M., Abadi, E. A. M., \& Kalhoran, M. H. (2015). Facts and theories through literature Review. International Journal of Medical Reviews, 2. Retrieved from http://www.ijmedrev.com/article_68654.html

Shahzad, A. H., Rehman, K. U., \& Saqib, M. (2018). Does stress impact school students learning? Asia Pacific Institute of Advanced Research. Retrieved from https://apiar.org.au/wp-content/uploads/2018/04/19_APCAR_2018_BRR713_Edu_38-44.pdf

Valentine, J., Dubois, D., \& Cooper, H. (2004). The relation between self-beliefs and academic achievement: A meta-analytic review. Educational Psychologist, 39(2), 111-133 https://doi.org/10.1207/s15326985ep3902_3 


\section{Macrothink}

International Journal of Social Science Research

ISSN 2327-5510 2020, Vol. 8, No. 1

Vogel, S., \& Schwabe, L. (2016). Learning and memory under stress: implications for the classroom. NPJ science of learning, 1, 16011. https://doi.org/10.1038/npjscilearn.2016.11

Yaribeygi, H., Panahi, Y., Sahraci, H., Johnston, T., \& Sahebkar, A. (2017). EXCLI Journal, 16, 1057-1072.

Zhang, J. F., Kuusisto, E., \& Tirri, K. (2017). How teachers' and students' mindsets in learning have been studied: Research findings in mindset and academic achievement. Psychology, 8, 1363-1377. https://doi.org/10.4236/psych.2017.89089

\section{Glossary}

Fixed Mindset: the mindset is the mindset in which people have a belief that your ability and intelligence are fixed traits. It is a student's beliefs that a talent alone creates success without effort and interprets mistakes as a sign that a person lack talent.

Growth Mindset: a belief that learning, abilities, talents, and intelligence can develop or improve by time, practice, and effort. Having a growth mindset is essential to lifelong success.

Mindset: the people way of thinking and the assemblage of people's opinions, idea, beliefs and knowledge.

Stress: a feeling caused by the situations or circumstances. It is the feeling of worry, tension, pressure, anxiety, and nervousness.

Stress level: the rate of people's feeling (worry, tension, pressure, anxiety, and nervousness).

\section{Appendix}

Appendix 1.Survey Questionnaire for Mindset and Stress

\section{Tool: checklist}

Directions: Read the statement and put a check to your corresponding answer.

\begin{tabular}{|c|c|c|}
\hline Scale: & 2- Sometimes & 3- Always \\
\hline I. & FIXED MINDSET & 123 \\
\hline 1. & I see workloads as a burden & \\
\hline 2. & I see effort is pointless & \\
\hline 3. & I easily quit or give up & \\
\hline 4. & I avoid taking up challenges & \\
\hline 5. & I criticize and judge others & \\
\hline 6. & I believe that my intelligence are inborn & \\
\hline 7. & I believe that my talent is fixed & \\
\hline 8. & I believe that, if I am not good in a particular subject then I forever am & \\
\hline & I easily think that I can't do it & \\
\hline 10. & I get easily tired when making outputs & \\
\hline
\end{tabular}




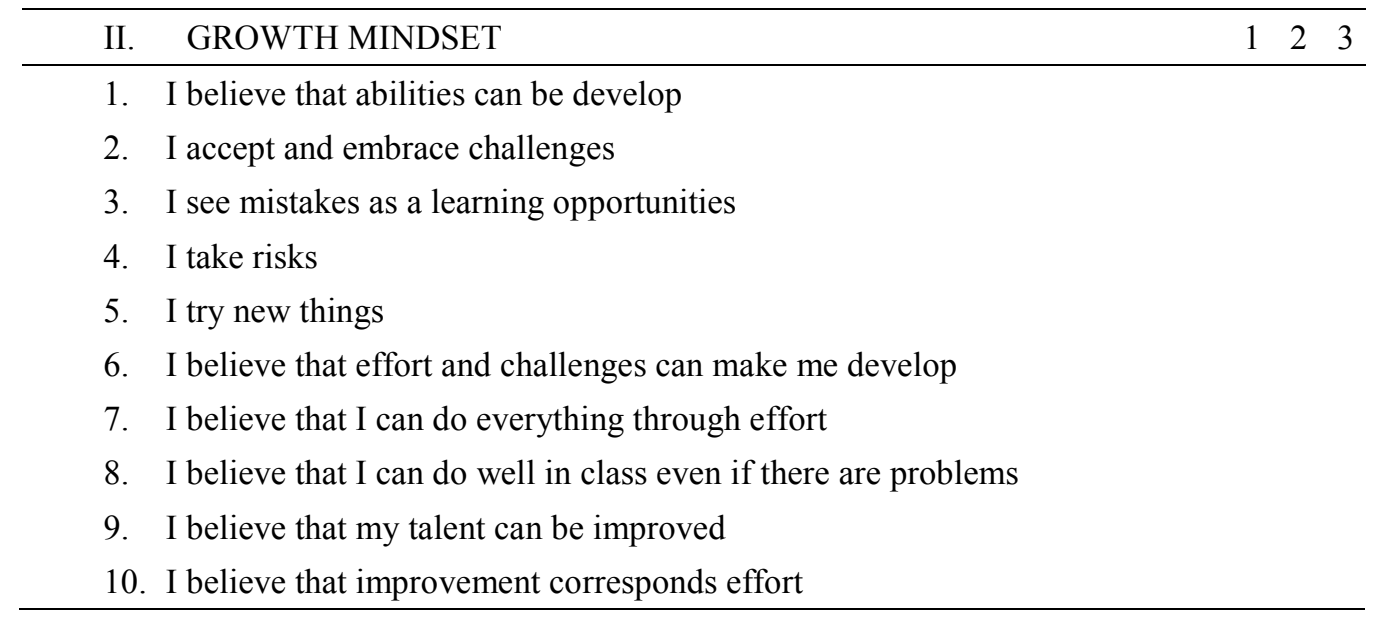

III. STRESS

A. PHYSICAL INDICATORS

1. My body feel tense all over

2. I have a nervous sweat or sweaty palms

3. I have a hard time feeling really relaxed

4. I get severe or chronic headaches

5. I get tension or muscle spasm in my face, jaw, neck, or shoulders

Retrieved from:https://docplayer.net/20677652-Stress-indicators-questionnaire.html

B. SLEEP INDICATORS

1. I have trouble falling asleep

2. I take pills to get to sleep

3. I have nightmares or repeated bad dreams

4. I wake up at least once in the middle of the night for no apparent reason.

5. No matter how much sleep I get, I awake feeling tired

\begin{tabular}{cl}
\hline Retrieved from:https://docplayer.net/20677652-Stress-indicators-questionnaire.html \\
\hline C. & EMOTIONAL INDICATORS \\
1. I have trouble remembering things \\
2. I feel anxious or frightened about problems I can't really describe \\
3. I worry a lot \\
4. I have temper outburst I can't control \\
5. It's best if I don't tell even my closest friend how I'm feeling \\
\hline Retrieved from: https://docplayer.net/20677652-Stress-indicators-questionnaire.html
\end{tabular}

\section{Copyrights}

Copyright for this article is retained by the author(s), with first publication rights granted to the journal.

This is an open-access article distributed under the terms and conditions of the Creative Commons Attribution license (http://creativecommons.org/licenses/by/4.0/). 